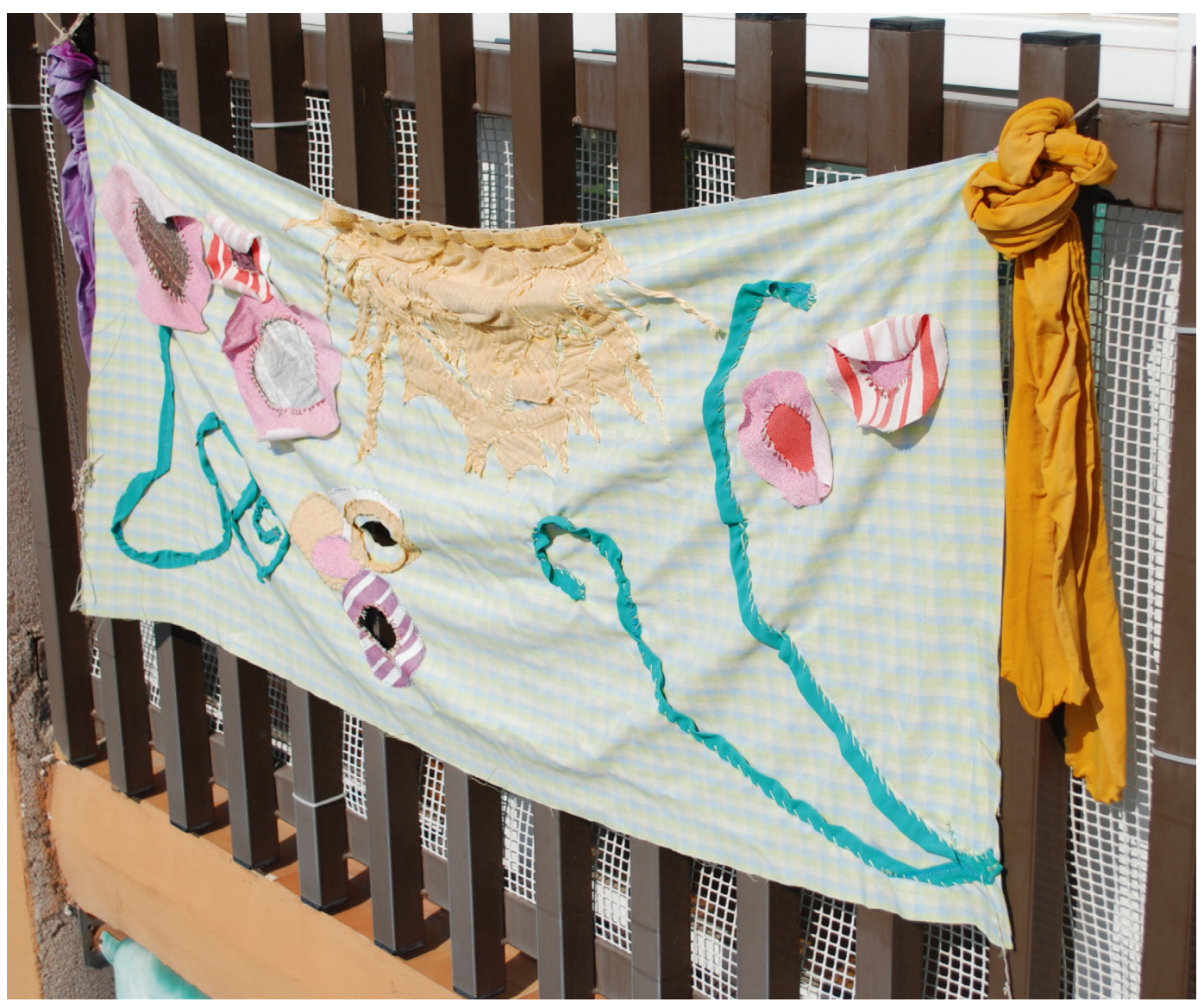

\title{
Un sol para vestir mi balcón
}

\section{Reflexión}

Durante el confinamiento, Eva Mesas, Ana Pérez y yo lanzamos por las redes la convocatoria Vestir los balcones. El crecimiento orgánico de la obra atrapaba a mis seres queridos y cercanos que, con sus imágenes, generaron un entorno simbólico acogedor donde pude pasar esos difíciles días. Para mi balcón, confeccioné un sol remendado sobre fondo verde que mantengo como huella de aquel lugar protector.

\section{Autora}

Eva Santos Sánchez-Guzmán

Máster en Arteterapia por la Universidad de Murcia.

Asosiación MURART.

Arteterapia: papeles de arteterapia y educación artística para la integración social.

Monográfico: Las miradas del arte y el arteterapia en tiempos de la Covid19. ISSN-e: 1988-8309 https://dx.doi.org/10.5209/arte.75882 